STUDIA ROSSICA POSNANIENSIA, vol. XXXIX: 2014, pp. 275-284. ISBN 978-83-232-2747-2. ISSN 0081-6884. Adam Mickiewicz University Press, Poznań

\title{
ЛИТЕРАТУРНАЯ НОРМА В ЯЗЫКЕ СМИ
}

\author{
LITERARY LANGUAGE IN THE MASS MEDIA
}

\author{
ТАТЬЯНА НИКОЛАЕВА
}

\begin{abstract}
This article shows the latest trends related to expanding the vocabulary used by the media. Particular attention is paid to the assimilation of borrowings and errors into this language as well as the issue of using obscene vocabulary.
\end{abstract}

Татьяна Николаева, Казанский университет, Казань - Россия.

В последние десятилетия стремительно происходят радикальные перемены в обществе, которые создают новые возможности для коммуникации. Понятно, что первыми реагируют на них средства массовой информации, которые ныне принято называть „массмедиа”. Заметим, что чем большая открытость творчества журналистов, тем большая их ответственность за письменную и разговорную языковые сферы, за соответствие нормам русского литературного языка.

Норму мы понимаем как общественно установленное, общепринятое и закрепившееся в языке использование языковых средств, реализующихся на разных языковых уровнях. Иначе говоря, норма - это система правил, которые „регламентируют употребление языковых единиц в речевой коммуникации, требуя от носителя литературного языка четко соотносить стилистические особенности, смысловые и экспрессивные оттенки параллельных способов выражения с конкретным контекстом или речевой ситуацией"1. При этом обязательным условием соответствия норме является сознательное отношение к языку. Сегодня приходится признать, что соблюдение орфоэпических, грамматических, лексических, стилистических норм в речевой коммуникации является редкостным явлением. В этом убеждает анализ языка журналистов-репортеров, комментирующих ход соревнований на только что прошедшей Олимпиаде в Лондоне, куда были мобилизованы лучшие силы России - журналисты с высокой профессиональной подготовкой. Перечислим наиболее типичные ошибки в орфоэпии:

1 Ю.А. Б е л ь ч и к о в, Стилистика и культура речи, Москва 1999, с. 109. 
Сильный удар, нанЕсенный нашими баскетболистами...;

Вся подготовительная работа нацелена на то, чтобы наши спортсмены стали здоровее, красивЕе;

В график соревнований по тяжелой атлетике внЕсены некоторые изменения; Обладателям золотых медалей врУчат премию в один миллион рублей;

Смотрите, как легко пОднялся спортсмен Франции над планкой в прыжке с шестом;

У Родберса не было намерЕния толкнуть противника;

В результате подобной афЁры...;

Наши легкоатлеты всегда стремились в верхОвенству в этом виде спорта;

В беседе с редакторАми Елена Исанбаева призналась, что сама не ожидала столь низкого результата;

В совремЁнный период ставятся оценки по иному принципу;

ПравЫ те, кто не предрекал победу нашим волейболисткам;

Теперь нам надо прИнять все меры, чтобы добиться победы;

Вот-вот она вклЮчит вторую скорость;

ХозяевА Олимпиады устроили овацию нашим юным гимнасткам;

Этот инциНдент произошел во время игры в баскетбол с испанцами;

Василий Мосин мастерскИ провел стендовую стрельбу;

Кенийская женская команда скомпромеНтировала себя приемом допинговых средств;

Был проведен конфЕДЕЦиальный разговор с каждым из участников соревнований по рапире;

Это был мощный аргУмент, способствующий исправлению ситуации;

Сегодня Лена позвОнит домой, чтобы поделиться своей радостью с родителями - победа! и др.

Столь же многочисленны ошибки на других структурных уровнях: в морфологии, синтаксисе, стилистике.

Что касается лексики, то настоящим бичом современной коммуникации являются лишние слова-паразиты, засоряющие и снижающие культурный уровень речи: значит, ну-у, это самое, так сказать, в общем, короче, что ми и особенно как бы, без которого в речевой практике не обходится даже самый образованный, интеллигентный человек, включая прежде всего работников печати, радио и особенно - телевидения. Насколько можно судить по заключениям психологов и психиатров, как бы является своеобразной „передышкой” в процессе формирования мысли, однако с точки зрения речевой культуры и языковой нормы использование его трудно оправдать:

Форум прошел как бы успешно;

Актеру Домогарову как бы понравился сценарий фильма;

Коммунисты привели как бы убедительные доводы;

Телеведущая Оксана Федорова как бы родила сына за границей;

Рекомендуемые лекарства как бы не помогли. 
Сегодня при анализе тенденций языковых изменений в средствах массовой информации обращает на себя внимание то, что в результате влияния социально-политических событий, а также отмены идеологической и в определенной степени литературно-языковой цензуры, в какой-то степени следящих за чистотой языка, различия между языковой нормой в журналистике и языковым узусом усиливаются, все более употребительными становятся неологизмы, модернизмы, иностранные слова, просторечная и жаргонная лексика.

Среди наиболее явственно проявляющихся тенденций в изменении и пополнении словарного состава в языке массмедиа можно назвать следующие:

1) Влияние молодежного жаргона: прикол, классный, крутой, туфта, предки, шнурки - родители, друган, короче, блин (эвфемизм к ругательству), клёво, кайф (от турецкого keif 'приятное безделье, ничегонеделание'), пурга - ерунда, попса, простой, тусоваться (производные: тусовщик, тусовщица, тусовка), драйв, панки, общак, рокеры, фанаты, хиппи, мент, атас - тревога, кореш, в натуре, жесть! - потрясающе хорошо и плохо (проявление энантиосемии) и др.

2) Активизация просторечия, иногда - продукта народной этимологии: видак, совок, телек, рыночник, гомосоветикус, дерьмократия, за бугром, развлекаловка; прихватизация; победители акции „Слово 2009 года” лексемы нехоть - состояние, когда ничего не хочется, брехлама - брехня и хлам, нанАтехнология - предвыборные подачки, гуглик - единица известности в интернете, фррендёж - расширение списка друзей (френдов), вампьютер - человек, попавший в компьютерную зависимость.

3) Включение иноязычной лексики. Это а) интернационализмы: альтернативный, конверсия, синдром, демократизация, консенсус, нонконформизм, конструктивный диалог, коррупция, плюрализм, популизм, хунта, б) англицизмы в языке экономики: ^изинговый бизнес, брокер, демпинг, клиринг, лобби, маркетинг, менеджер, рейтинг, рэкет, в) заимствования из других европейских языков: дранг нах остен, политика аншлюса, мафия - мафиози - мафиозник, мэр, мэрия, г) кальки: альтернативная служба, движение зелёных, деполитизация, европейский дом, европеизировать, многопартийная система, правовое государство, рыночная экономика, совместное предприятие, администрация, тоталитаризм, фреминизм.

4) Распространение реалий изменившейся политической жизни: афрганеи, гласность, застой, перестройка, кагебешник-гебист, особист, омоновеи, босьмёрка, горбачёвщина, жириновщина, мемориалеи, пикет, неформал, аппаратчик, советская империя, разгосударствление, демдвижение, деморосс.

5) Возрождение исторической лексики, вышедшей из языкового употребления: коммерция, коммерсант, торги, купечество, миллионер, милииардер, атаман, гимназия, мицей, господин (госпожа), сударь (сударыня), 
благотворительность, духовность, милосердие, покаяние, модернизм, акмеизм, футтуризм, абстракционизм. Сюда же можно отнести использование библейских лексем: каинова печать, египетская казнъ, нищие духом, святая святых, кромешная тьма.

6) Внедрение метафорической или эпатажной лексики, включенной в синтагмы, которая, как правило, используется как средство создания пародии, иронии: Из негра сделали мясной рулет, Московских изыган прижмут к ногтю, Вселенский хай, Канадские халявщики, Испанские страсти в казанском притоне, Пенсия на два чиха.

7) Введение социальных стандартов: макаронники - итальянцы, лягушатники - французы, загадочная русская душа, ловкие пакистанцы, черномазый, лица кавказской национальности.

8) Использование лексики, демонстрирующей отклонение от толерантных норм межэтнических отношений: экстремизм, этнофобия, ксенофобия, расизм, национализм, антисемизм, шовинизм.

9) Приспособление языка к новой общественной ситуации, что осуществляется прежде всего с помощью следующих приемов:

- коннотация: застой, медведи, диссиденты, недрормалы, ортодоксы, бабки, зелёные, тёлка, бойфренд;

- вытеснение реалий советского общества: соииализм, социиалистический лагерь, комсомольиы, многостаночница, субботник, ночная смена, передовик;

- использование советизмов в качестве средства создания иронии: мудрый вождь, светлое будущее, отеи всех народов, великий кормчии;;

- процесс криминализации языка, активизация воровского жаргона, что приводит к вульгаризации языка журналистов: брать на понт - разыгрывать, понтоваться - изображать из себя то, что ты на самом деле не представляешь, сходняк - собрание, шалабон, зихер - нехороший поступок, легавый, пахан, лох, фрраер, крышевание, бакланить - разговаривать, щевельнуть - украсть, нагон - освобождение, алес - плохо и др.

Перечисленные семантические новации преследуют несколько целей: модернизировать и демократизировать язык, сделать его приспособленным к употреблению в обществе, быть понятным человеку новой формации.

Хотелось бы обратить внимание на то обстоятельство, что в языке средств массовой информации наблюдаются две тенденции, вызывающие обеспокоенность и тревогу блюстителей речевой культуры: 1) использование иностранных слов с ложной интерпретацией их семантики и 2) активизация проникновения в речевую коммуникацию ненормативной лексики.

Включение иноязычных слов в речь предполагает, прежде всего, семантическую и языковую компетентность, которая „взвешивает язы- 
ковые, психологические и социальные факторы и посредством их балансировки добивается таких речевых актов, которые являются приемлемыми на всех уровнях" 2 . Однако стремление сделать язык массмедиа путем использования иностранных слов более интеллектуально значимым подчас приводит к досадным ошибкам, неточностям и курьезам. Так, экономико-политический термин ваучер, чрезвычайно распространенный в России в конце прошлого, XX века, в английском языке имеет значение 'талон, дающий право на путешествие', на русской почве это слово почему-то переведено как 'приватизационный чек, связанный с современным процессом приватизации в России'.

Подверглась неоправданным семантическим преобразованиям и лексема будировать, которая в силу фонетического сходства с будить (паронимия) используется не во французском значении 'дуться, сердиться' (bouder), а в трансформированном 'возбуждать, тормошить, будить, толкать, тонизировать, вдохновлять, призывать к чему-л.'. Вместе с тем, хотя в большинстве современных словарей это слово не зафиксировано, в речевой практике до сих пор оно довольно часто используется в значении 'побуждать к действиям'.

Нами был проведен анализ ошибок, допущенных в газетах „Московский комсомолец”, „Комсомольская правда”, „Известия”, „Вечерняя Казань”, , „Аргументы недели”, в использовании заимствований:

„Интернационалистическая группа преступников, в составе которой чеченец, таджик, украинец и русский, обвела вокруг пальца своих охранников, как детей" (неточный выбор слова, обусловленный паронимией: интернациональныи - интернационалистический);

„На киностудии «Мосфильм» мы попали в эпицентр съемочного процесса" (эпищентр - точка проекции подземного или атмосферного явления на земную поверхность. В данном случае приемлема лексема иентр);

„Болельщики казанской команды хоккеистов были шокированы поражением «Ак барса»" (шокированы - поставлены в неловкое положение, употреблено в несвойственном значении, правильно - потрясены);

„Шлягером сезона стала пресс-конференция, которую артисты впервые провели после концерта" (лексема шлягер предусматривает многократное проведение какого-либо мероприятия);

„Коллеги из Санкт-Петербурга блестяще провели эту агитационную компанию" (правильно - кАмпанию);

„Какие же критерии надо заложить в фундамент наших знаний, чтобы они отвечали требованиям современной науки?" (критерии в фундамент не закладывают);

2 Т.Р. Б е л л, Социолингъистика. Цель, методы и проблемы, Москва 1980, с. 22. 
„Ждите экспансии креативных людей” (creative в англ. "созидательный, творческий', в данном случае более уместно - талантливый).

В современной речи журналистов, а также выступающих по телевидению и радио обозревателей, чиновников, бизнесменов, политических деятелей наблюдается интенсификация использования просторечной лексики, жаргонизмов и арготизмов.

Если говорить о просторечном лексическом слое, то следует заметить, что в научной литературе сложился термин „литературное просторечие", который вносит весьма существенное уточнение в саму проблему соотношения и взаимодействия с русским литературным языком ${ }^{3}$. Это лексико-стилистическая категория, исторически обусловленная. Ее выделение стало возможным в послепушкинский период и является следствием формирования общенациональной литературной нормы. Она представляет собой разновидность разговорной литературной речи и стилистически маркированный пласт литературного языка. Таким образом, термин „просторечие” целесообразно рассматривать в двух аспектах: литературное просторечие - нарочитое использование просторечных слов в пределах нормы со стилистическими целями и нелитературное, обусловленное недостаточной образованностью, а точнее - отсутствием речевой культуры. В целом понятие „просторечие" в применении к русскому литературному языку противоречиво и расплывчато, что способствует подчас сложному отмежеванию его от так называемых грубых инвективных слов - жаргонизмов и арготизмов. Судя по трактовке в МАС номинации инвектива - 'резкое выступление против кого-либо, чего-либо, оскорбительная речь', эти термины подчас трудно различить. В самом деле, чем отличается по эмоциональной выразительности использование следующих оценочных слов:

Доллар падает, дерьмо всплывает (простореч.);

Когда задница мерзнет, удовольствие получаешь колоссальное (простореч.);

Журналистам изначально выдали карт-бланш - говорить все, только не срать "b кепку" (жаргон);

Вы нам расхерачили всю республику, так давайте теперь денег на восстановление (жаргон);

Он опять наехал на своего собеседника (арго, воровской жаргон);

Пусть они в Европе утрутся своим евро (простореч.);

У тебя говняная передача, греешь жопу (простореч.);

Вот это - настоящий мужик, не педик (жаргон);

Попытки этих агрессоров надо мочить в сортире (арго, жаргон).

${ }^{3}$ Ю.С. С о р о к и н, Развитие словарного состава русского литературного языка (30-90-е годы ХІХ века), Москва-Ленинград 1965, с. 24; Ф.П. Ф и л и н, Истоки и судьбы русского литературного языка, Москва 1981, с. 151. 
В свете сказанного становится понятной позиция В.В. Химика, который объединяет просторечие с ненормативной лексикой (арго, сленг, жаргон), однако трудно согласиться с ученым, который считает эту лексику „значимым элементом культуры” студенческого жаргона 1980-х годов: „Ну я тащусь! А ты простой! Айда похиляем в гадюшник мясца на клык навалить". Ср. в наше время: „Слышь, кореш, шнурки в стакане отчалили, давай приваливай. Сечешь?". Или жаргонизмы сегодняшних студентов Казанского университета: зихер - плохой поступок, рамсы попутать - вести себя неадекватно, колбаситься - танцевать, кайфолом - нежелание что-н. делать, сбрызни - уйди, корщик - человек, который смешит людей, кекс - жених, „Че гонишь фруфло - жесть!". Что это - значимые элементы нашей культуры?

Борьба с языковыми элементами, засоряющими речь, в свое время была объявлена А.М. Горьким, который в словах-„,сорняках" и выражениях типа подъялдыкивать, скукоживаться, шамать, волынить, буза, мура на большой палец, с присыпкой, катись кВадратной колбасой видел опасность, грозящую речевой культуре. В статье $О$ словотворчестве Ильенкова он писал:

Ценность его „словотворчества” сомнительна. „Взбрыгнул, трушились, встопорчил, грякнул, буруздил" и десятки таких плохо выдуманных словечек, все это - даже не мякина, не солома, а вредный сорняк, и есть опасность, что семена его дадут обильные всходы, засорят наш богатый, сочный, крепкий литературный язык.

Безусловно, наша речь должна быть насыщена эмоционально-экспрессивными интонациями, о чем говорил Л.В. Щерба: без подобной лексики „литературный язык становится шарманкой, не способной выражать какие-либо мысли" 5 . Но значит ли это, что необходимо использовать слова, которые выходят за пределы литературной нормы и в настоящее время имеют номинацию „ненормативная лексика?”.

О причинах и закономерностях появления жаргонов и арготизмов и важности их изучения писал еще И.А. Бодуэн де Куртенэ, будучи редактором 3-го издания словаря В.И. Даля (1903):

Научная точность каждого толкового словаря со стороны самого материала является в отражении действительности в жизни и воззрениях данного народа. Если жизнь является дикою и безобразною, составитель или же редактор должен примириться с этим печальным фактом и не может ограничиваться замалчиванием. Сказанное относится ко всему: сквернословиям, ругатель-

${ }^{4}$ В.В. Х и м и к, Поэтика низкого или просторечие как культурный феномен, Санкт-Петербург 2001, с. 103.

5 Л.В. Щ е р б а, Языковая система и речевая деятельность, Ленинград 1974, с. 277. 
ствам, мерзостям площадного жаргона. Лексикограф не имеет права урезывать и кастрировать „живой язык”. Раз известные слова существуют в умах громадного большинства народа и беспрестанно выливаются наружу, лексикограф обязан занести их в словарь, хотя бы против этого восставали и притворно негодовали все лицемеры и тартюфы, являющиеся обыкновенно большими любителями сальностей по секретуб.

Впоследствии, в предисловии к словарю В.Ф. Трахтенберга Блатная музыка (1908), И.А. Бодуэн де Куртенэ подтвердил мысль о необходимости изучения „тайного” языка, „жаргона тюрьмы”, или „блатной музыки", составляющей

достоверный материал для психолога, для этолога (теоретика или историка этики или нравственности), для юриста (теоретика и практика), для фольклориста, для исследователя народной словесности и прежде всего для лингвиста или языковеда. Блатная музыка - есть один из русских „говоров”, конечно, не в обыкновенном смысле этого слова.

Сам термин блатной перешел из немецкого через польский. Немецкое blat - 'доверенный, согласный на что-либо', польское blat - 'укрыватель краденого', blatny, btatny - то же, что в русском арго. Эти лексемы (блат - преступление, блатной - член преступного мира) впервые зафиксированы в словаре В.Ф. Трахтенберга.

Указывая на титульной обложке, что словарь составлен

по материалам, собранным в пересыльных тюрьмах: Петербургской, Московской („Бутырки”), Виленской, Варшавской, Киевской и Одесской, в тюрьмах: в „Крестах”, в „Доме предварительного заключения”, в „Дерябинских казармах" (ПБг), в „Каменщиках" (Москва),

И.А. Бодуэн де Куртенэ вносит коррективы в понимание самой номинации „жаргон тюрьмы”, которая многими воспринимается слишком локально: это словарь не только воров, мошенников и шулеров, но и некоторых других профессий, заслуживающих „не столько презрения, сколько сострадания и прощающего понимания" (да и вообще, пишет ученый, „где грань между преступным и неприступным миром?") ${ }^{7}$. Обратим внимание на то, что высказывания И.А. Бодуэна де Куртенэ нацелены не на популяризацию употребления жаргонной лексики, а на использование ее в качестве богатого источника, необходимого для научных исследований, прежде всего - филологических изысканий.

${ }^{6}$ И.А. Б о д у э н д е К у р т е н э, Предисловие к 3-му изданию „Словаря живаго великорусскаго языка" В.И. Даля, Москва 1903, с. 3-4.

7 И.А. Б о д у э н д е К у р т е н э, Предисловие к Словарю В.Ф. Трахтенберга „Блатная музыка", Москва 1908, с. 3-6. 
В наше время проблемами жаргонной лексики занимается профессор Саратовского университета О.Б. Сиротинина, которая провела четкую классификацию жаргонизмов: молодежный, торговый, жаргон наркоманов, уголовников, музыкальный - и показала их функциональную значимость как средств, позволяющих автору наиболее точно воспроизвести картину жизни описываемой социальной группы, а главное - передать авторское отношение, эмоционально-экспрессивно выразить оценку событию, явлению, личности. „Эмоциональная оценка, как правило, негативная, обладает большим спектром оттенков - от легкой иронии до прямого осуждения"8.

Снятие запретов, свобода слова в сегодняшней коммуникации привели к тому, что жаргонная лексика беспрепятственно появляется в статьях на серьезные экономические, общественно-политические темы, в материалах о политических лидерах и представителях власти: со страниц газет на читателя обрушиваются сарказм, скепсис, издевательство, едкая насмешка.

Наиболее популярные слова - жаргонизмы и арготизмы: бабки, крыша, мент, тусовка, беспредел, засветиться, прикольно - зафиксированы в современных словарях с пометой „разг.” и тем самым стилистически нейтрализуются, переходя в разряд нормативной лексики, пополняя словарный запас литературного языка9 .

Сегодня наблюдается интенсивный процесс внедрения мата - „неприличной матерной брани”, которую МАС интерпретирует как „просторечие". О распространенности непристойной, ругательной лексики свидетельствует репортаж с 3-го Одесского фестиваля журналистки Людмилы Ворониной:

В картине „Жить” вообще сплошная чернуха. Становится неловко, когда мат исторгается из уст блондинки-депутатши от „Единой России” Марии Кожевниковой. Ушат брани вылили на зрителей и создатели ленты „Чемпион из подворотни”, причем 50-летний актер и отец двух дочек Алексей Горбунов, представляющий фильм, убежден: „В нашей жизни без мата нельзя! Вас просто никто не поймет. Кстати, женский мат тоже приветствую. И своих дочек постепенно приучаю на нем разговаривать".

И это демонстрируется на всю страну... Как кажется, комментарии здесь излишни.

8 О.Б. С и р о т и н и н а, Современный публицистический стиль русского языка, „Russistik” 1999, № 1-2, с. 115.

${ }_{9}^{9}$ См., например, Большой толковый словарь русского языка, гл. ред. С.А. Кузнецов, Санкт-Петербург 2001; Толковый словарь русского языка начала ХХІ века, под ред. Г.Н. Скляревской, Москва 2007; Большой академический словарь русского языка, гл. ред. К.С. Горбачевич, Москва-Санкт-Петербург 2004. 
Неизбежно возникает вопрос: к чему ведут современные процессы в языке средств массовой информации, в первую очередь - активизация употребления ненормированной лексики? Это покажет будущее. Ясно одно: любое речевое явление, использованное без мотивации и грубо нарушающее литературную норму, свидетельствует о низком культурном уровне говорящего и достойно негативной оценки общества. Пришло время критического анализа сложившейся ситуации и перехода к практическим действиям. 